\title{
STRATEGI KOMUNIKASI PASAR PAYUNGI DALAM MEMBANGUN IMAGE PASAR KREATIF
}

\author{
Yemima Ika Puspitania ${ }^{1 *}$, Zon Vanel ${ }^{2}$ \\ Universitas Kristen Satya Wacana, Kota Salatiga, Indonesia \\ *yemimaika76@gmail.com \\ Submitted: 08-09-2021, Revision: 23-09-2021, Accepted: 28-12-2021
}

\begin{abstract}
This research stems from researchers interested in the creative market in the city of Metro Lampung which can inspire many people with social media so that many people come to study and travel. Of course, researchers have a goal in research, namely to find out and describe what marketing communication strategies are carried out by the umbrella market in building an image as a creative market in Metro City. The research method in this study is phenomenological research which is carried out when researchers want to understand a phenomenon from a different point of view, for example from the point of view of certain individuals or groups who experience it. The data obtained in the study to determine the marketing communication strategy of the Payungi market was by using in-depth interviews, documentation and also observations of the location, the initiators of the Umbrella market, the chairman of the Umbrella market and also the seller in the Umbrella market who served as informants and tested the validity of the data. The results of this study prove that the communication strategy carried out by the umbrella market is based on marketing communication theory, namely advertising, public relations, sales promotion, events and experience, and direct sales. The researcher also recommends that marketing should be propagated through other media such as print media, newspapers, radio, billboards, banners to make it easier for the wider community who are still not familiar with social media.
\end{abstract}

Keywords: communication strategy; marketing; image; creative market; payungi market

\begin{abstract}
Abstrak
Penelitian ini bermula dari peneliti tertarik mengenai pasar kreatif di kota Metro Lampung yang dapat menginspirasi banyak orang dengan media sosial sehingga banyak orang yang datang untuk belajar dan berwisata. Tentunya peneliti memiliki tujuan dalam penelitian yaitu Untuk mengetahui dan mendeskripsikan strategi komunikasi pemasaran apa saja yang dilakukan oleh pasar payungi dalam membangun image sebagai pasar kreatif di Kota Metro. Metode penelitian dalam penelitian ini adalah Penelitian fenomenologi yang dilakukan saat peneliti ingin memahami suatu fenomena dari sudut pandang yang berbeda misalnya dari sudut pandang individu atau kelompok tertentu yang mengalaminya. Data yang diperoleh dalam penelitian untuk mengetahui strategi komunikasi pemasaran pasar Payungi adalah dengan menggunakan wawancara mendalam, dokumentasi dan juga observasi terhadap lokasi, penggagas pasar payungi, ketua pasar payungi dan juga penjual di pasar payungi yang sebagai informan serta menguji keabsahan data. Hasil dari penelitian ini membuktikan bahwa strategi komunikasi yang dilakukan oleh pasar payungi dilakukan berdasarkan teori komunikasi pemasaran yaitu pengiklanan, hubungan masyarakat, sales promotion, event dan experience, serta direct sales. Peneliti juga merekomendasikan bahwa pemasaran sebaiknya lebih diperbanyak melalui media-media lain seperti media cetak Koran, Radio, baliho, banner agar mempermudah masyarakat luas yang masih belum mengenal media sosial.
\end{abstract}

Kata Kunci: strategi komunikasi; pemasaran; image; pasar kreatif; pasar Payungi

\section{PENDAHULUAN}

Kota Metro merupakan salah satu kota di provinsi Lampung yang dikenal sebagai kota pendidikan dan juga kota wisata keluarga berbasis ekonomi kerakyatan berlandaskan pembangunan partisipatif. 
Berdasarkan hasil survey Badan Pusat Statistik (BPS) pada tahun 2007, Kota Metro disebutkan sebagai kota pendidikan karena kota Metro memiliki pendidikan yang cukup lengkap dan memiliki sekitar $65 \%$ pelajar SMA dan $85 \%$ pelajar SMK yang berasal dari berbagai daerah di Lampung. (METRO, 2019)

Menurut Hana Nur Fadilah mengungkapkan bahwa Suatu merek harus memiliki keunggulan bersaing yang menjadi alasan bagi konsumen untuk memilih merek tertentu. Keunikan asosiasi merek dapat berdasarkan atribut produk, fungsi produk atau citra yang dinikmati konsumen. Idealnya, untuk mengokohkan brand image sebuah perusahaan diperlukan strategi komunikasi dan pendekatan yang sesuai dengan kebutuhan perusahaan dan dapat menembus tujuan utama perusahaan. (Fadhilah, 2016)

Pasar payungi adalah sebuah pasar kreatif pertama dikota Metro dengan design dan budaya yang kreatif yang menyediakan berbagai wahana diantaranya adalah kampung pelangi, flying fox, lebah trigona, rumah kelinci, wahana panahan, permainan tradisional, rumah baca pojok boekoe cangkir, lempar pisau dan juga kedai delussy cangkir kopi. Pasar payungi didirikan dengan adanya inisiatif dari para warga berdaya yang percaya bahwa perubahan bisa dilakukan dengan cara gotong royong. Pasar payungi juga diciptakan selaras dengan programprogram pemerintahan terkait dengan penciptaan desa yang mandiri.

Berdasarkan data yg didapat dilapangan, Pasar Payungi bermula dari sekelompok warga pada sebuah Kelurahan Yosomulyo yang ingin membangun ekonomi masyarakat menjadi lebih baik. Pasar Payungi memberikan ruang baru bagi tumbuhnya kebudayaan atau kebiasaan baru dengan mempertahankan keaslian dari Indonesia (tradisional) serta warga ditekankan untuk memperhatikan keramahan lingkungan sekitar. Jika warga yang bertahun-tahun notabene adalah petani, pembuat bata, buruh dan lainnya kini mereka memiliki kebiasaan membuat kuliner tradisional yang dikemas dengan promosi media sosial sehingga pasar payungi lebih dikenal oleh masyarakat luas dan pendapatan dari pasar payungi akan meningkat juga. Pasar payungi juga diketahui memberikan kesempatan untuk masyarakat berperilaku ekonomis dan kreatif dengan memanfaatkan alam, sebagai contoh membuat produk makanan dari bahan dasar umbi-umbian, sayuran, serta kacang-kacangan. Dengan jerih payah yang dilakukan oleh berbagai warga kini Pasar Payungi mencatat omset gelaran 1 Miliar 34 juta pada tanggal 5 Mei 2019 (Lampung, 2019). Sebuah capaian yang berhasil didapat karena solidaritas dan kreatifitas para warga yang mendukung pergerakan dari pasar payungi.

Strategi komunikasi pemasaran yang dilakukan oleh pasar payungi adalah efektif karena dalam 2 tahun saja, pasar payungi dapat meningkatkan ekonomi masyarakat sekitar melalui promosi pada media sosial. Untuk itu penulis ingin meneliti lebih lanjut mengenai strategi komunikasi pemasaran yang digunakan oleh pasar payungi dalam membangun Image sebagai pasar yang kreatif.

Pada tahun 2019, penelitian yang dilakukan oleh peneliti bernama Nofha Rina dan juga Ruri Wahyu Yuriadi melakukan penelitian untuk strategi komunikasi pemasaran dalam mempertahankan brand image brownies Amanda sebagai kue oleh-oleh bandung. Dalam penelitian disebutkan bahwa strategi komunikasi pemasaran yang dilakukan oleh Amanda Brownies adalah Promosi pada komponen bauran yang dibagi menjadi 4 yaitu Product, Place, Price, dan Promotion dan hasil dari penelitian ini adalah konsep yang dilakukan brownies Amanda cocok digunakan dalam strategi pemasaran brownies Amanda karena tetap menjaga Rebranding produk mereka sebagai kue 
khas nusantara yang tersebar disemua wilayah Indonesia. (Rina \& Yuriadi, 2019)

Pada tahun 2017, ada juga sebuah penelitian mengenai strategi komunikasi pemasaran terpadu bali united dalam membangun brand image sebagai klub sepakbola professional. Penelitian ini dilakukan oleh Hady Yuliarta, dkk hasil dari penelitian ini adalah Bali United atau klub sepakbola menggunakan media komunikasi pemasaran sebagai strategi komunikasi pemasaran terpadu dalam membangun citra merek sebagai klub sepak bola yang profesional. Media tersebut yaitu periklanan, promosi penjualan, pemasaran langsung, pemasaran interaktif/internet. Hubungan masyarakat, dan penjualan pribadi. (Suryawati et al., 2015).

Dari hasil ke 2 penelitian dalam 10 tahun terakhir maka dalam penelitian ini memiliki rumusan masalah yaitu Bagaimana strategi komunikasi pemasaran pasar payungi dalam membangun image sebagai pasar Kreatif di Kota Metro. Tujuan dari penelitian ini adalah untuk mengetahui dan mendeskripsikan strategi komunikasi pemasaran apa saja yang dilakukan oleh pasar payungi dalam membangun image sebagai pasar kreatif di Kota Metro apakah sama dengan penelitian sebelumnya atau tidak. Juga dari dari penjelasan tersebut dapat diketahui bahwa sebenarnya pemasaran merupakan suatu kegiatan untuk menawarkan barang atau jasa oleh individu atau suatu kelompok yang ditujukan untuk kepuasan konsumen agar setia dan menjadi konsumen tetap melalui kegiatan yang berhubungan dengan pembuatan suatu produk, penetapan harga, promosi, pendistribusian produk, sehingga mencapai target yang diinginkan seperti yang dikutip pada jurnal Sumiyati. (L. Murdiyanto \& Sumiyati, 2018)

\section{METODOLOGI}

Pendekatan penelitian yang digunakan dalam penelitian ini adalah pendekatan kualitatif. Adapun yang dimaksud dengan penelitian kualitatif yaitu penelitian yang bermaksud untuk memahami fenomena dari situasi yang ada mengenai apa yang sedang dialami oleh subjek penelitian secara keseluruhan, dan dengan cara deskriptif, dalam bentuk katakata dan bahasa, pada suatu konteks khusus yang alamiah dan dengan memanfaatkan berbagai metode ilmiah (Wahyuningrum, 2012).

Jenis penelitian deskriptif kualitatif yang digunakan pada penelitian ini dimaksudkan untuk menggali suatu data yang didapatkan dilapangan atau dalam suatu pengamatan, adapun alasan penulis memilih deskriptif kualitatif karena ingin menjabarkan atau menjelaskan bahwa dengan adanya pasar payungi di Kota Metro menjadi dampak yang positif bagi masyarakat di kota Metro dengan strategi IMC yang digunakan oleh Pasar Payungi dalam membangun image-nya sebagai pasar yang kreatif. Karena keberhasilan dari suatu penelitian deskriptif kualitatif adalah bahwa penelitian ini dapat dipahami tentang fenomena yang dialami oleh subjek penelitian misalnya pada perilaku, persepsi, motivasi, tindakan, dll secara holistic, dan dengan cara mendeskripsi dalam bentuk kata-kata atau bahasa yang dibuat sedemikian rupa pada suatu konteks khusus yang alamiah dan dengan memanfaatkan berbagai metode alamiah. (E. Murdiyanto, 2020)

Penelitian ini menggunakan beberapa teknik pengumpulan data yaitu: wawancara, dokumentasi, dan juga observasi terhadap sumber data. Serta menggunakan beberapa teknik dalam menganalisa data yang dibedakan menjadi beberapa bagian diantaranya ialah pengumpulan data, reduksi data, penyajian data serta kesimpulan. Kemudian penelitian ini menggunakan teknik validitas data dengan 3 trianggulasi yaitu trianggulasi sumber, trianggulasi teknik dan trianggulasi waktu. Menurut (Sugiyono, 2012:327), teknik pengumpulan data 
triangulasi diartikan sebagai teknik pengumpulan data yang bersifat menggabungkan dari berbagai teknik pengumpulan data dan sumber data yang telah ada.

Lokasi penelitian ini beralamat di jalan kedondong, kelurahan Yosomulyo, kota Metro Pusat, provinsi Lampung. Lokasi penelitian ini sesuai dengan topik yang ingin di teliti maka peneliti langsung menuju ke lokasi yang telah ditentukan sebelumnya. Sumber data dari penelitian ini terbagi menjadi 2 yaitu data primer dan sekunder. Sumber data primer dalam penelitian ini adalah Dharma Setyawan selaku penggerak dari pasar Payungi dan memiliki pengaruh cukup besar di pasar Payungi. Pengambilan data primer ini dilakukan dengan metode purposive random sampling sedangkan data Sekunder dalam penelitian ini, dokumentasi merupakan sumber data sekunder. Jenis dokumentasi yang dilakukan pada penelitian ini adalah catatan peristiwa yang ada, dokumen dapat berbentuk gambar, tulisan ataupun karya seseorang. Dokumen yang berbentuk gambar dalam penelitian ini adalah foto-foto seperti, foto kegiatan, foto pasar payungi dari pembangunan hingga saat ini. Dokumen yang berbentuk tulisan dalam penelitian ini adalah sejarah dari pasar payungi atau biografi serta peraturan yang ada pada pasar payungi. Dan dokumen yang berbentuk karya seni seseorang dalam penelitian ini adalah berupa sovernir dan berbagai karya seni yang dapat ditemukan pada pasar payungi sebagai image-nya membangun pasar kreatif di Kota Metro.

Adapun teknik pengumpulan data dalam penelitian ini yang dibagi menjadi 3 (wawancara, dokumentasi, observasi). Dalam penelitian ini, wawancara mendalam akan dilakukan oleh Dharma Setyawan sebagai penggerak dari Pasar Payungi, karena seorang penggerak pasti tahu mengenai informasi hingga data yang dibutuhkan oleh si peneliti untuk melengkapi dokumen penelitian. Dalam penelitian ini juga, peneliti menggunakan dokumentasi untuk mencari data serta informasi seputar payungi pada informan yang terkait dengan pasar payungi seperti penggerak pasar hingga anggota yang ada pada pasar payungi. Serta, Dalam penelitian ini jenis observasi yang dilakukan oleh peneliti adalah participant observation karena peneliti terlibat langsung dalam kegiatan yang ada pada Pasar payungi dan mengamati situasi pasar payungi.

\section{HASIL DAN PEMBAHASAN}

Pada hasil wawancara dengan narasumber Pasar Payungi, mas Dharma Setiyawan yang sebagai penggagas dari pasar payungi memaparkan Payungi didirikan pada tanggal 28 Oktober 2018, berawal dari sebuah kampung warna-warni yang dibangun dari bulan Mei sampai bulan Oktober, kemudian pada 28 Oktober 2018 dibukalah pasar kuliner tradisional yang akan digelar setiap hari minggu dari pukul 6 pagi hingga 11 siang. Setahun kemudian pengurus dari pasar payungi mendirikan payungi University yaitu sekolah alternative bagi anak muda untuk belajar, mengenai media sosial berbentuk digital, pemberdayaan masyarakat dan ekonomi yang kreatif. Selain itu, pasar payungi juga berkembang menjadi banyak hal, selain gelaran pasar kuliner tradisional di setiap hari minggu dari jam 6 pagi - jam 11 siang dengan berbagai wahana seperti panahan, flying fox, taman kelinci, galeri foto, Pasar payungi juga mendirikan beberapa kedai kopi yang disebut dengan kampung kopi payungi yang buka pada setiap malam, payungi juga mendirikan kampung bahasa inggris bagi anak - anak yang ingin belajar serta berlatih berbahasa inggris, pesantren wirausaha dan juga women environment studi yaitu pusat kajian perempuan dan lingkungan hidup, serta payungi mendirikan sekolah desa penggerak wisata. Dalam 2,5 tahun setelah didirikannya, pasar Payungi mampu mendapatkan penghasilan sebesar 4.5 milliar dan juga pagelaran 
payungi telah mencapai omset 45 juta -50 juta, maka dari itu Payungi dianggap sebagai pasar yang menginspirasi banyak orang atas apa yang telah dicapainya dalam kurun waktu yang cukup singkat.

Mas Dharma Setyawan memaparkan pasar payungi ini adalah pasar yang menginspirasi banyak pasar - pasar yang akan dan baru buka yang ada untuk terus berkembang untuk wadah masyarakat yang mau berkarya, "masyarakat adalah pemilik sah dari apa yang dikerjakan, karena semua yang telah dikerjakan ini akan kembali kepada masyarakat dan untuk masyarakat", ujarnya.

Dari hasil penelitian ditemukan strategi komunikasi pemasaran dalam pasar Payungi, yaitu: Strategi komunikasi pemasaran di Pasar Payungi dilakukan dengan berbagai upaya baik secara offline maupun online untuk mempromosikan Pasar Kreatif Yosomulyo Pelangi di Kota Metro sebagai tempat wisata keluarga serta menjadi tempat edukasi yang efektif bagi masyarakat. Payungi juga mendidik beberapa ibu-ibu untuk aktif dalam bersosial media dan mengikuti perkembangan zaman kekinian yang berbasis teknologi. Strategi komunikasi pemasaran yang telah dilakukan oleh pasar payungi sudah efektif dan mendatangkan hasil yang baik juga seperti banyak orang yang datang untuk berkunjung dan juga belajar, bahkan pasar payungi telah menginspirasi banyak orang untuk ikut berpartisipasi dalam kegiatan yang menguntungkan masyarakat dengan membangun pasas-pasar yang kreatif sebagai tempat menyalurkan ide dan bakat dari berbagai masyarakat yang mau untuk berkarya lebih lagi.

Merujuk kepada jenis dari IMC dalam penelitian ini, peneliti menemukan dan menganalisa dari hasil wawancara kepada pengurus pasar Payungi, yaitu sebagai berikut: 1. Iklan; Pasar payungi menggunakan iklan dalam mempromosikan pasar payungi melalui media sosial seperti Instagram, Youtube, Website, Fanspage. Pada gambar 1, diketahui followers pada akun instagram @ payungi_mencapai 6.993 orang dengan banyak postingan 1.759 serta jumlah like pada postingan yang lebih dari 100 orang, dengan banyaknya jumlah followers, postingan dan like pada akun instagram tersebut maka peneliti menyimpulkan bahwa pasar payungi cukup aktif dalam media sosial. Dalam Instagram juga terdapat fitur-fitur yang bisa dimanfaatkan oleh para peenggunanya. Adapun fitur-fitur yang membantu dalam pemasaran atau promosi barang dan jasa yang di jual secara online. (Rahman \& Panuju, 2017)

Berikut adalah salah satu iklan yang ada pada postingan instagram @ payungi_iklan tersebut berbentuk gambar atau poster yang di design dengan latar belakang pada gambar merupakan orang banyak yang sedang berada di pasar Payungi, pada iklan tersebut memiliki kata "payungi is Back" yang berarti payungi kembali, yang memiliki maksud ialah payungi merupakan pasar yang hanya buka setiap satu minggu sekali yaitu di hari minggu saja, sedangkan dalam masa Pandemic seperti ini banyak warung makan yang ditutup tetapi pasar payungi ini mengumumkan bahwa payungi kembali, pada poster tersebut juga ada katakata "besok banget", berarti postingan ini diunggah pada hari Sabtu, 22 Mei 2021 dan Ahad, dalam kamus besar bahasa Indonesia berarti Hari Minggu, serta blok warna biru yang tetap mengingatkan tentang protokol kesehatan bagi para pengunjung agar tetap aman saat berkunjung ke pasar payungi. Jadi iklan ini memberikan informasi bahwa payungi tetap di buka pada hari minggu tanggal 23 Mei 2021 dengan penerapan protokol kesehatan yang berlaku dan wajib dipatuhi oleh masyarakat. 


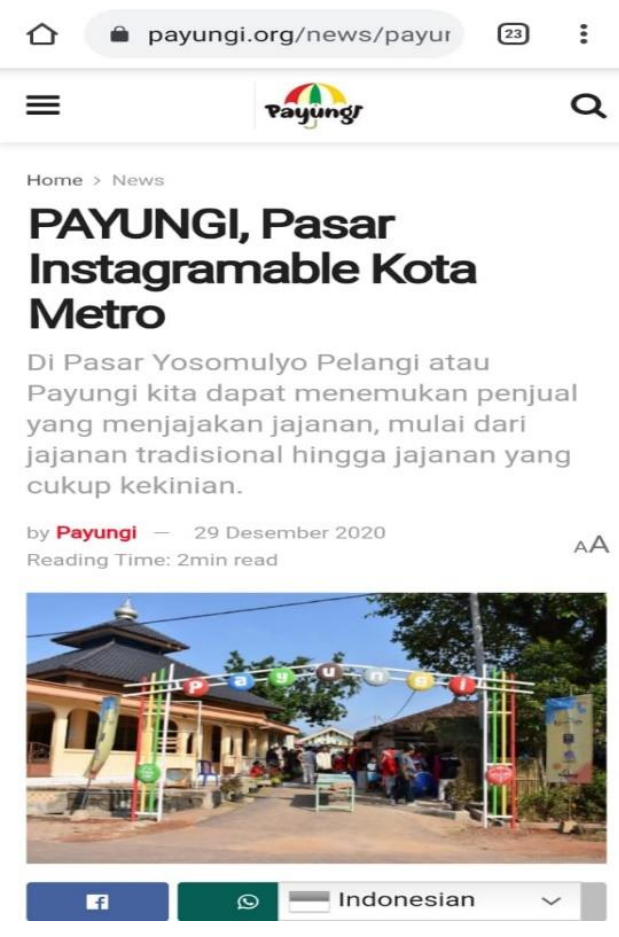

Gambar 1. Iklan Payungi is Back

(Sumber: instagram payungi, 2021)

Pada gambar 2 dapat kita lihat, itu adalah sebuah website pasar payungi yang digunakan sebagai media untuk informasi dan promosi, website Payungi adalah Payungi.org, isi didalam website payungi pun beragam dari berita atau informasi seputar talkshow, sekolah desa, serta prestasi Local Heroes dan seterusnya yang berkaitan dengan pasar payungi. Salah satu iklan yang terdapat pada website pasar payungi adalah berbentuk berita atau disebut dengan iklan advetorial, iklan advetorial ini biasanya digunakan untuk membangun citra pada sebuah perusahaan atau organisasi agar diminati masyarakat. (Lukitaningsih Ambar, 2013) Iklan advetorial pada website payungi.org berjudul Payungi, pasar Instagramable di Kota Metro. Dari judul ini terlihat bahwa payungi sedang membangun image-nya sebagai pasar yang Instagramable atau kekinian karena pada masa kini sebuah tempat dikatakan kreatif jika memiliki fungsi yang beragam, bagus dan juga menarik maka dengan adanya artikel pada website payungi dapat membuat image yang baik pada pasar Payungi.

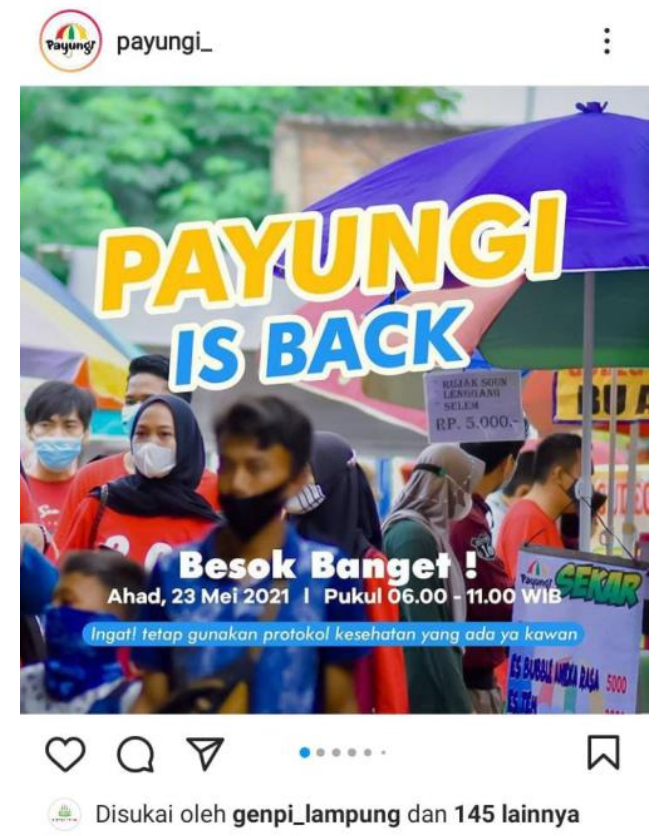

Gambar 2. Iklan pada website Payungi (Sumber: website payungi.org, 2020)

Pada gambar 3, dapat kita lihat youtube dari pasar payungi, akun youtube ini bernama Payungi University, total jumlah postingan youtube dari payungi sendiri ada 46 video dengan jumlah subscriber mencapai 270 orang. Rata-rata postingan youtube pada akun youtube payungi ini terkait dengan edukasi dan sumber informasi seperti materi mengenai apa itu Trilogi pembangunan desa, payungi dan gerakan warga, bicara mengenai pusat studi desa, media digital serta lagu payungi sebagai jingle atau sebuah iklan yang di realisasikan dalam bentuk musik yang di ciptakan oleh Dharma Setyawan pengagas dari pasar payungi. Lirik lagu Payungi tersebut berisikan gambaran dari sebuah pasar payungi dengan berbagai kuliner dan wahana bermain serta belajar, sang pencipta ingin orang-orang yang mendengarkan lagu ini seperti merasakan hal yang sama sewaktu berada di pasar payungi dan menjadikan pasar payungi ini penuh dengan kenangan yang indah, 
berikut adalah lirik lagu yang berjudul Payungi;

"Hari minggu jangan berdiam diri, bangun pagi lalu segera mandi,Kita nikmati jajanan di payungi, ada wahana bermain dan belajar, Memancing ikan dan juga panahan, ada kampung kelinci di payungi

Reff:

Pasar Yosomulyo pelangi, ada cinta disini

Cerita indah di kota ini, pasar Yosomulyo Pelangi, Senyum di pagi hari, denganmu yang selalu di hati, Nikmatnya pagi minum kopi, Dibawah pohon bambu kita bernyanyi Nikmatnya kuliner pagi di Payungi."

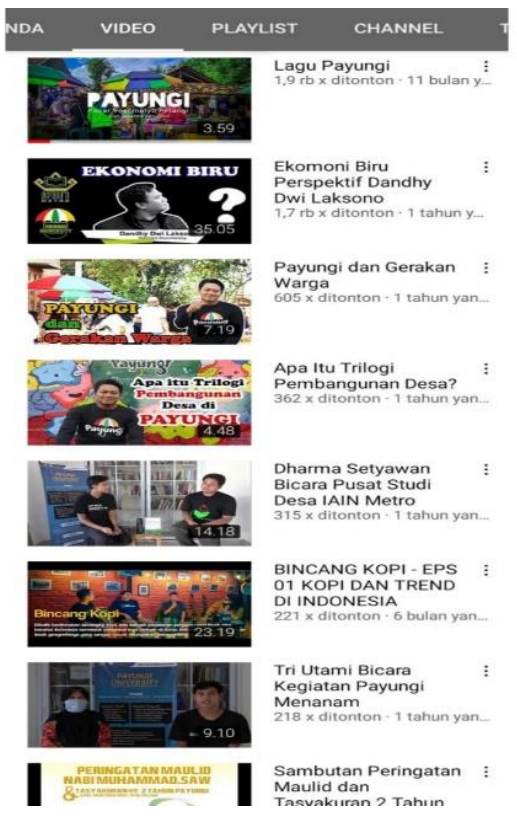

Gambar 3. Youtube Payungi (Sumber: youtube payungi, 2020)

Selain akun media sosial Instagram, website dan youtube, pasar payungi juga memiliki Fanspage di facebook dengan nama Gallery Payungi Metro, yang dapat kita lihat pada gambar nomor 4. Berikut adalah salah satu iklan yang terdapat dalam postingan payungi adalah iklan dalam bentuk poster, iklan ini mempromosikan Sekolah Penggerak Pariwisata yang didirikan sendiri oleh pasar Payungi, dalam poster tersebut terdapat foto para pengurus dari pasar payungi dan didalam poster tersebut dijelaskan waktu, lokasi, fasilitas serta biaya yang dibutuhkan untuk orang yang ingin mengikuti Sekolah Penggerak Pariwisata.

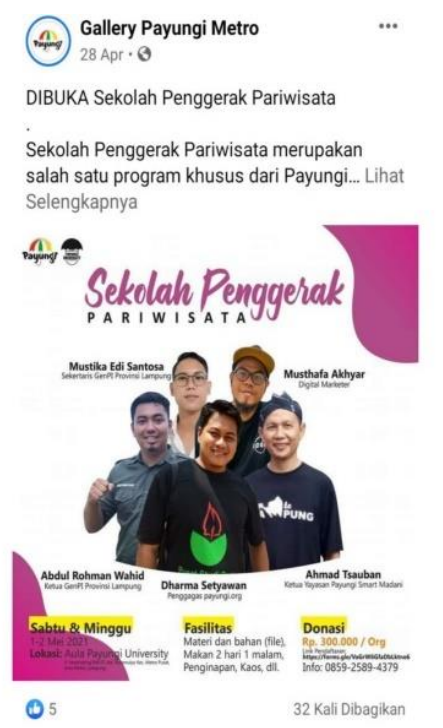

Gambar 4. Facebook Payungi

(Sumber: instagram payungi, 2020)

Hubungan Masyarakat, Pasar payungi juga membuat hubungan dengan masyarakat melalui pendekatan yang cukup efektif seperti pendekatan keagamaan, sifat kemanusiaan dengan bekerja sama saling bergotong royong mengadakan sedekah serta membuat masyarakat berpikir kreatif untuk mengubah ruang kreatif menjadi lebih cantik dengan mengubah berbagai spot yang ada untuk tempat selfie yang membuat suasana pasar payungi menjadi lebih menarik dan dikunjungi oleh banyak orang. 


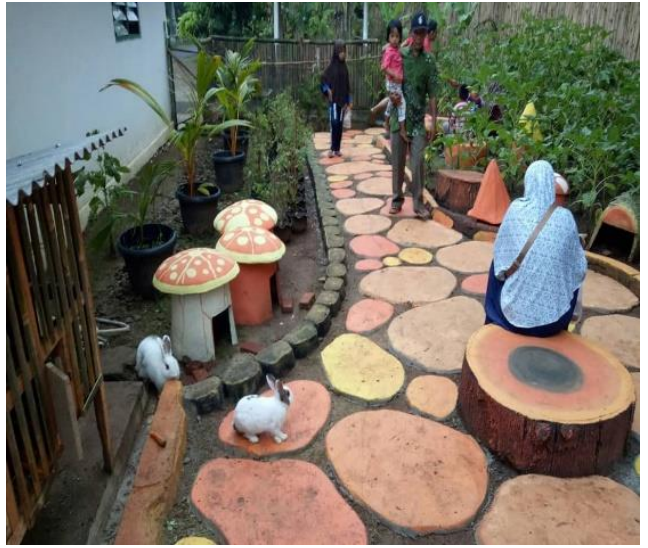

Gambar b1. Hubungan masyarakat Payungi (Sumber: instagram payungi, 2020)

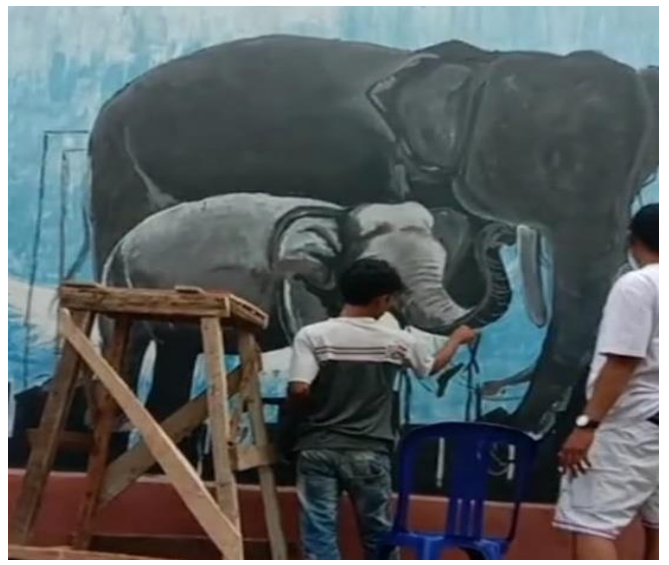

Gambar b2. Hubungan Masyarakat Payungi

(Sumber: instagram payungi, 2020)

Pada gambar b.1 dan b.2 dijelaskan bahwa hubungan masyarakat yang dilakukan oleh pasar payungi dengan membuat sebuah tempat menjadi lebih cantik dengan taman kelinci yang di cat dan di berikan berbagai ornamen untuk menambah kesan instagramable yang menarik untuk dijadikan tempat wisata masyarakat sedangkan pada gambar b2 adalah sebuah mural gajah yang dibuat untuk menambah kesan yang cantik dan bisa dibuat untuk swafoto bersama keluarga atau teman-teman yang datang ke pasar payungi. Kedua gambar tersebuat adalah salah satu program kerja yang telah berjalan untuk membuat pasar payungi menjadi lebih menarik dan mendapatkan banyak cap sebagai pasar yang kreatif di kota Metro.
Adapun hubungan masyarakat yang dilakukan oleh payungi yaitu bergotong royonng membersihkan tempat atau lokasi dari pasar payungi yang sudah terjadwal setiap hari Sabtu dan juga Minggu sore agar tempat di pasar payungi selalu bersih dari sampah yang ada di daerah sekitar payungi. Berikut adalah gambar dari gotong royong yang dilakukan oleh pasar payungi sebagai wujud dari program kerja yang ada di pasar payungi yang telah di realisasikan selama kurang lebih 3 tahun dari didirikannya payungi di Kota Metro.

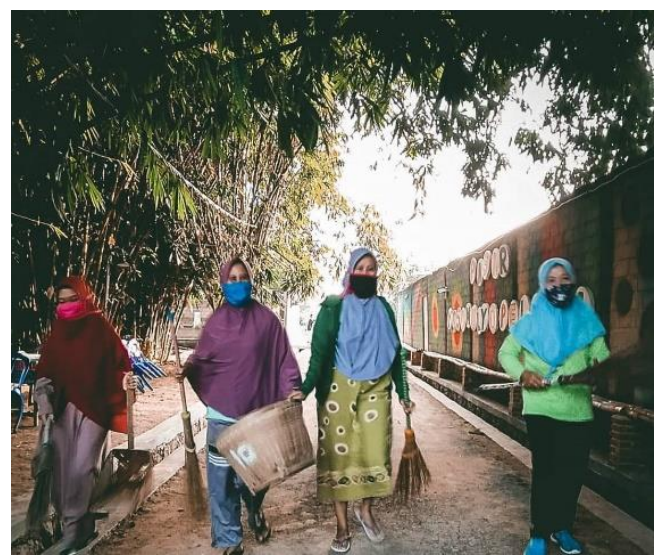

Gambar 3c. Hubungan Masyarakat Payungi

(Sumber: instagram payungi, 2020)

Menurut bu Tri pedagang di pasar payungi memaparkan bahwa pasar payungi ini berdiri atas gotong royong dari warga sekitar pasar Payungi ini, gotong royong pasar payungi dapat dilihat pada gambar 3c. maka dari itu hendaklah apa yang telah dibangun sejak awal tetap dipertahankan, karena apa yang telah diperbuat di awal dan mendapatkan hasil yang baik maka harus tetap di pertahankan hingga akhir dengan begitu hubungan masyarakat dapat terjalin dengan baik juga.

Pada gambar 5,6,7 adalah gambar sebuah Sales promotion dari pasar Pyungi, Payungi melakukan Sales Promotion dengan berbagai lembaga-lembaga yang bersangkutan seperti pemerintahan, perusahaan tertentu dan juga sekolahsekolah untuk mengenalkan pasar payungi 
yang kreatif serta memberikan pengetahuan dan pembelajaran mengenai pasar kreatif yang sedang dipersiapkan untuk masyarakat yang mau bekerja keras menyalurkan bakat kekreatifan yang ada sehingga memberikan kesan yang dapat menguntungkan juga bagi masyarakat dan kegiatan Sales Promotion ini sangat berpengaruh bagi payungi karena sales promotion menjadi bentuk dukungan bagi pasar payungi untuk berkembang. Payungi bekerjasama dengan im3 dan juga Germas, Sasa untuk melakukan kegiatan Sales Promotion.

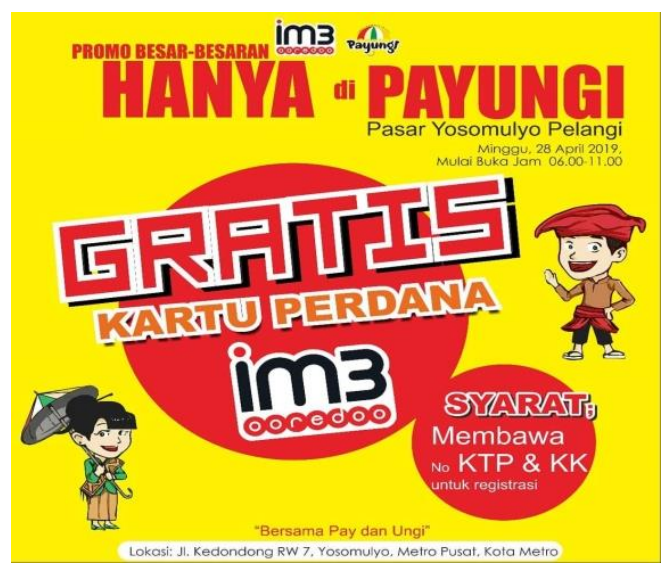

Gambar 5. Sales promotion im3 (Sumber: instagram payungi,2019)

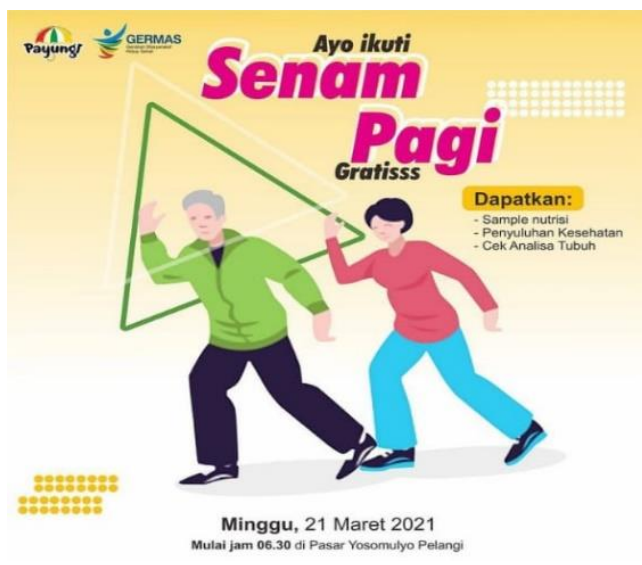

Gambar 6. Sales promotion Germas (Sumber: instagram payungi, 2021)

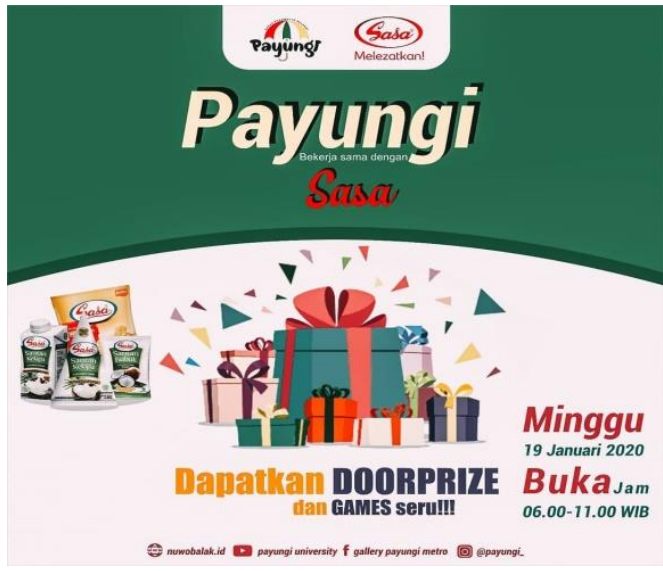

Gambar 7. Sales promotion Sasa

(Sumber: instagram payungi, 2020)

Strategi komunikasi yang ke 4 adalah event dan experience, Payungi juga memiliki banyak event disetiap minggu nya seperti Live Music, Live Cooking, serta lomba - lomba seperti stand up comedy dengan pendaftaran gratis dan berhadiah bagi pemenangnya dan juga mengadakan seminar atau pengajaran mengenai media sosial, sekolah penggerak wisata dan lainnya yang berkaitan dengan pengetahuan. Event yang dilakukan oleh payungi ini berhasil membuat pengunjung menjadi lebih ramai. Event yang diadakan oleh payungi salah satunya adalah fun kompetisi lomba stand up comedy dalam rangka memperingati hari anti narkoba Internasional (HANI) pada tanggal 26 Juni 2021. Dalam hal ini payungi bekerjasama dengan Genpi Lampung untuk mensukseskan acara lomba ini. Kompetisi stand up comedy ini terbuka untuk umum bahkan pendaftarannya pun gratis namun pemenang lomba akan mendapatkan hadiah berupa uang pembinaan bagi juara 1,2 dan 3 serta free sertifikat bagi para peserta yang berpartisipasi dalam lomba.

Menurut salah satu pengurus dari pasar payungi memaparkan bahwa event yang diadakan kali ini cukup meriah karena dihadiri oleh kurang lebih 100 penonton yang terdiri dari kalangan remaja serta masyarakat umum dengan total peserta ada 15 orang. Kompetisi lomba ini merupakan salah satu bentuk dari kegiatan penyebaran 
informasi mengenai Pencegahan dan Pemberantasan Penyalahgunaan dan Peredaran Gelap Narkotika (P4GN) dengan mengangkat nilai-nilai kesenian kreatif bagi para masyarakat khususnya generasi millenial kota Metro dalam melestarikan budaya bangsa serta menyuarakan "hidup sehat tanpa narkoba" serta menyuarakan semangat "war on drugs" yang ditujukan kepada pemuda untuk menumbuhkan kesadaran serta perubahan perilaku dan juga karakter untuk menghindari penyalahgunaan dan peredaran dari narkoba di Kota Metro. Gambar 8 adalah salah satu dokumentasi acara yang diadakan oleh Pasar Payungi.

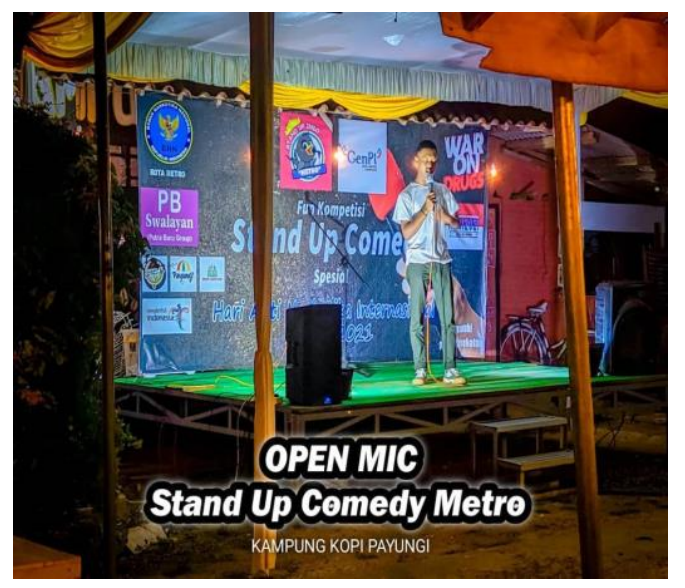

Gambar 8. event payungi

(Sumber: instagram payungi, 2021)

Direct sales, Pasar payungi melakukan direct selling dengan cara menyediakan tempat yang menarik untuk belajar serta berwisata. Dalam hal ini payungi didukung dengan gerakan masyarakat yang mendorong untuk menjadi pasar gotong royong yang kreatif dengan kesenian atau budaya yang ada serta memanfaatkan digitalitas agar mempromosikan pasar payungi ini, uniknya pasar ini dilakukan oleh warga sendiri dalam kelurahan Yosomulyo kecamatan Metro pusat dan bagi para pelaku penjualan di pasar payungi juga merupakan warga asli dari kelurahan tersebut bahkan para pedagang yang berjualan di pasar payungi juga harus mematuhi seluruh persyaratan yang ada seperti gotong royong yang dilakukan di hari Sabtu sebelum kegiatan gelaran hari Minggu dan sesudah gelaran, infaq ke masjid dan juga melakukan diskusi yang diadakan setiap hari Senin, maka dari itu pedagang harus siap dan berkomitmen dengan apa yang telah disepakati bersama. Pasar payungi ini bukan hanya sekedar pasar untuk melakukan transaksi jual beli semata tetapi pasar payungi ini telah berkembang menjadi pasar yang memiliki pengetahuan di dalamnya dan juga memiliki konsep-konsep yang tidak dimiliki oleh pasar yang lainnya seperti budidaya lebah yang disebut dengan trigona lebah, kemudian ada sekolah-sekolah media digital serta mendidik ibu-ibu yang tidak bisa menggunakan media sosial menjadi bisa bermedia sosial seperti contoh dahulu sebelum diajarkan media sosial cara berdagang mereka menggunakan mulut kemulut atau haya sekedar langganan lama dan baru namun sekarang para ibu-ibu yang berjualan di pasar payungi mendapatkan edukasi sehingga para ibu-ibu ini bisa mempromosikan dagangannya kemedia sosial.

Inilah sebabnya pasar payungi dapat dijuluki sebagai pasar yang kreatif di Kota Metro, karena pasar Payungi ini berbeda dengan pasar lainnya, dipasar payungi kini banyak dikenal oleh publik dan juga media massa dan telah menjadi pusat penelitian bagi banyak mahasiswa serta dosen yang ingin mengetahui lebih lanjut mengenai pasar kreatif ini.

Dalam pembangunan image dikalangan masyarakat atau publik, sebuah perusahaan atau lembaga harus mampu membangun image yang positif agar kelak mampu bertahan dalam jangka waktu yang lama untuk masyarakat percaya akan sebuah perusahaan atau lembaga tersebut. (Wibowo, 2018) Khususnya pasar payungi, pasar payungi tentu harus membangun imagenya untuk kedepannya masyarakat lebih banyak yang mengenal tempat 
tersebut hingga dapat dikatakan sebagai tempat favorit dari beberapa masyarakat. Oleh karena itu maka pasar payungi memiliki pembuktian program kerja yang dapat menarik minat dari masyarakat karena image yang positif dari konsumen terhadap suatu brand maka sangat memungkinkan untuk para masyarakat yang jauh untuk datang walau hanya berkunjung saja. (Kejora, 2019) Dalam pembangunan image maka perlu adanya beberapa tindakan yang tentunya dapat membangun image yang baik di mata masyakarat. Pasar payungi telah membangun imagenya sebagai pasar payungi dengan berbagai cara berikut ini; menentukan visi dan target pasar, visi dari pasar payungi adalah membentuk kesadaran dari masyarakat untuk bersatu dan mengembangkan kreatifitas pada sebuah Pasar Yosomulyo Pelangi (payungi) akan lebih menjamin keberlangsungan kegiatan perekonomian. Maka dari itu misi yang dijalankan oleh pasar payungi semerta-merta untuk mengembangkan kreatifitas masyarakat dan juga membantu perekonomian masyarakat sekitar. Selanjutnya payungi menentukan karakternya yaitu menjadi pasar yang bukan hanya sekedar pasar biasa, melainkan memiliki pengetahuan didalamnya dan bermanfaat bagi semua orang. Pasar payungi mampu mengubah pola pikir beberapa masyarakatnya untuk hidup mengikuti perkembangan zaman, seperti wawancara yang dilakukan oleh pengurus dari pasar payungi yang mengatakan bahwa ibu-ibu yang awalnya tidak mengerti mengenai media sosial dan bagaimana cara penggunaannya, saat ini ibu-ibu menjadi lebih berwawasan dan mampu mengaplikasian media sosial dengan cepat. Maka dari itu masyarakat pun dapat mempelajarinya bahkan payungi pun membuat sekolah khusus untuk mempelajari media digital, payungi juga menyampaikan karakternya kepada masyarakat luas dengan cara membuat logo. Pasar payungi memiliki logo yaitu berbentuk payung dengan berbagai warna seperti gambar berikut ini;

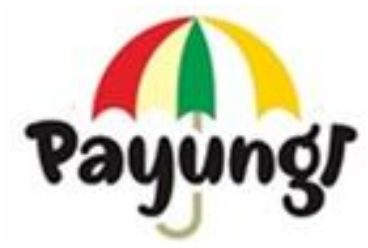

Gambar 9. logo Payungi

(Sumber: website payungi.org, 2019)

Selain logo payungi juga memiliki slogan yaitu "Payungi tumbuh dengan kebersamaan, gotong royong, dan cinta." Serta payungi juga menentukan karakternya dengan tampilan atau postingan yang ada pada media sosial khususnya pada instagram yang diperkuat dengan disain yang menarik seperti tone warna, karakter dari postingan serta informasi atau isi atau pesan yang dibagikan di media sosial instagram tersebut. Logo payungi dapat dilihat pada gambar 9 logo payungi.

Selanjutnya payungi melakukan promosi dengan menggunakan mouth to mouth dan juga media sosial karena selain media sosial ternyata word of mouth masih cukup efisien dan gratis dan bisa kapanpun digunakan karena masih banyak orang yang belum mengerti mengenai media sosial maka dari itu mouth to mouth masih digunakan dalam mempromosikan sesuatu. (Pamungkas \& Zuhroh, 2016)

Dan yang terakhir dalam pembangunan image sebagai kreatif payungi harus meneruskan konsistensinya Pasar payungi meneruskan konsistensinya dengan berpegang pada visinya yang mewujudkan kesadaran masyarakat ini terus ditingkatkan atau selalu di perbarui untuk kemajuan pasar yang lebih baik lagi tanpa menghilangkan karakter yang telah terbentuk sejak awal didirikannya payungi. (Kamarudin, 2019) Kunci dari konsistensi adalah dengan kerjasama, kerja keras serta pemahaman dan kesadaran yang jelas 
mengenai betapa pentingnya pasar payungi dalam mewujudkan cita-cita masyarakat serta menjadi kepercayaan masyarakat untuk belajar dan berwisata. Pasar payungi juga menerapkannya pada sistem keagamaan dan kesepakatan yang telah ditentukan semenjak awal bersama dengan tim, seperti persyaratan yang dibuat oleh tim untuk para pedagang yang ditandatangani diatas materai, maka dari itu konsistensi akan berjalan dengan baik selaras dengan tujuan yang akan dicapai.

Berdasarkan hasil observasi lapangan, peneliti menemukan bahwa sampai saat ini Pasar Payungi mendapatkan image sebagai pasar kreatif dengan citra yang positif membangun dan menginspirasi masyarakat. Citra ini didapatkan oleh pasar payungi karena memang payungi memiliki potensi, selain design tempat yang menarik pasar payungi kini banyak dikenal oleh banyak orang sebagai pasar yang baik untuk edukasi anak-anak maka tak jarang juga khalayak menyebut pasar payungi sebagai tempat rekreasi keluarga yang berbasis ekonomi kerakyatan karena di pasar payungi terdapat fasilitas yang cukup banyak seperti arena bermain anak-anak, berbagai pameran hingga kulineran ada di dalam 1 tempat yaitu pasar payungi. Pertahanan citra positif ini tentu membutuhkan perhatian khusus dalam hal mengelola serta mempertahankannya untuk waktu yang lama dengan menggunakan strategi komunikasi juga karena citra yang positif ini dapat terbilang sebagai program kerja atau kegiatan dari seluruh anggota dari pasar payungi atau salah satu tugas dari pengurus pasar payungi untuk terus berkarya dan tetap mempertahankan citra yang positif di tengah masyarakat. Kekurangan dari pasar payungi ini adalah tidak adanya program kerja yang jelas hanya saja berupa ide atau gagasan dari pengurus atau tim kemudian dibahas bersama dan disepakati bersama kemudian langsung dicoba untuk merealisasikan, seharusnya pasar payungi membuat daftar program kerja, agar apa yang terkerjakan lebih maksimal kembali dan lebih memuaskan daripada sebelumnya.

Berdasarkan beberapa hal di atas ini, maka peneliti menyimpulkan bahwa pasar payungi di Kota metro telah mencapai image yang baik di masyarakat sebagai pasar yang kreatif serta menginspirasi banyak orang. Namun, masih diperlukan untuk tetap mempertahanan dan meningkatkan citra positif tersebut.

\section{SIMPULAN}

Penciptaan image pasar payungi sebagai pasar kreatif di kota Metro ditentukan oleh strategi komunikasi pemasaran serta tata cara dalam membangun image positif di tengah masyarakat, strategi komunikasi pemasaran yang dilakukan oleh pasar payungi hampir keseluruhannya melalui sosial media, hubungan dengan masyarakat, Sales Promotion, Event dan Experience serta Direct Selling atau penjualan secara langsung, hal ini tentu didukung dengan karakter dari pasar payungi dan juga hal-hal yang menarik yang dapat ditonjolkan di pasar payungi dengan begitu pasar payungi dapat dikatakan sebagai pasar Kreatif di Kota Metro. Dengan adanya hasil penelitian yang telah berlangsung maka dari itu peneliti dapat menyimpulkan bahwa Keterlibatan para masyarakat dalam aktivitas marketing komunikasi yang ada di pasar payungi, akan memberi dampak yang positif terhadap ekonomi rakyat, media social dan lingkungan masyarakat sekitar. Hal ini juga akan menjamin terjadinya tempat wisata keluarga serta tempat edukasi yang keberlanjutan bagi masyarakat.

Berdasarkan pengamatan pada pasar payungi, peneliti ingin memberikan saran terkait dengan pasar payungi yaitu: Sebaiknya pihak pasar payungi menambahkan pengiklanan secara intensif tidak hanya melalui media sosial saja melainkan media cetak, radio karena masih banyak masyarakat yang masih belum 
mengenal media sosial maka dari itu diharapkan payungi dapat menggunakan media cetak seperti Koran, majalah serta membuat spanduk yang besar di tengah kota atau di pinggir jalan sebagai media promosi tambahan agar masyarakat yang tidak menggunakan media sosial pun ikut mengetahui dan mendukung adanya pasar payungi sebagai pasar kreatif di kota Metro. Selanjutnya, Sebaiknya pasar payungi lebih gencar lagi untuk melakukan kegiatan yang mengedukasi seperti pembelajaran media sosial dengan menargetkan anak-anak yang sekolahan, karena masa saat ini, anak-anak menggunakan media sosial dengan bebas sehingga tidak digunakan untuk kegiatan yang positif seperti belajar.

\section{DAFTAR PUSTAKA}

Fadhilah, H. N. (2016). Skripsi Strategi Komunikasi Marketing Public Relations Pt . Jiggie Teknologi Indonesia Dalam Membangun Brand Image Di Jakarta. Universitas Prof Dr. Moestopo.

https://library.moestopo.ac.id/

Kamarudin, S. (2019). Administrasi Dan Pelayanan Publik Antara Teori dan Aplikasinya.

https://www.researchgate.net/publicat ion/331341122_ADMINISTRASI_D AN_PELAYANAN_PUBLIK_Antar a_Teori_dan_Aplikasi

Kejora, S. C. (2019). "upaya membangun citra dan meningkatkan minat masyarakat di lembaga pendidikan islam melalui manajemen strategis public relations" [UIN Malang]. http://etheses.uinmalang.ac.id/14590/1/17710006.pdf

Lampung, kota M. (2019). omzet $1 \mathrm{~m}$. Facebook.

https://web.facebook.com/kotametrol pg/photos/1-miliar-

payungibersyukur-atas-nikmat-yangtelah-diberikan-tuhan-kepada-kitasem/428192111070779/?_rdc=1\&_rd $\mathrm{r}$

Lukitaningsih, A. (2013). Iklan Yang Efektif Sebagai Strategi Komunikasi Pemasaran Ambar Lukitaningsih Fakultas Ekonomi Universitas Sarjanawiyata Tamansiswa Yogyakarta. Jurnal Ekonomi Dan Kewirausahaan, 13(2), 116-129. https://ejurnal.unisri.ac.id/index.php/ Ekonomi/article/view/670

METRO, K. (2019). Tentang Kota Metro. Kemenkeu.Go.Id. https://www.djkn.kemenkeu.go.id/kp knl-metro/baca-artikel/12792/KotaMetro-Kota-Dengan-KemajuanPendidikan-yangMenggembirakan.html

Murdiyanto, E. (2020). Metode penelitian kualitatif. http://eprints.upnyk.ac.id

Murdiyanto, L., \& Sumiyati. (2018). Strategi komunikasi pemasaran pariwisata untuk meningkatkan kunjungan wisatawan di pantai suwuk kabupaten kebumen. Wacana: Jurnal Ilmiah Ilmu Komuniaksi, 17(2), 171180.

https://doi.org/https://doi.org/10.3250

9/wacana.v17i2.629

Pamungkas, B. A., \& Zuhroh, S. (2016). Pengaruh Promosi Di Media Sosial Dan Word Of Mouth Terhadap Keputusan Pembelian. Jurnal Trunojoyo, Vol. X no., 145-160. https://journal.trunojoyo.ac.id/komuni kasi/article/view/2518

Rahman, I. A., \& Panuju, R. (2017). Strategi komunikasi pemasaran produk. Jurnal Unitomo, 16(2), 214224.

http://repository.unitomo.ac.id/690/1/j urnal Wacana.pdf

Rina, N., \& Yuriadi, R. W. (2019). Mempertahankan Brand Image Brownies Amanda Sebagai Kue Oleh - Oleh Bandung. Jurnal Telkom University, 5(1), 66-73. https://doi.org/https://doi.org/10.2512 4/liski.v5i1 STRATEGI 
Sugiyono. (2012). Metode Penelitian Kuantitatif, Kualitatif, dan $R \& D$. Alfabeta.

Suryawati, I. G. A. A., Pascaran, N. N. D., \& Yuliartha, H. (2015). Strategi Komunikasi Pemasaran Terpadu Bali United Dalam Membangun Brand Image. Ejurnal Medium, 1(1), 1-8. https://ojs.unud.ac.id/index.php/komu nikasi/article/view/35435

Wahyuningrum, M. M. (2012). Partisipasi Orang Tua Siswa Dalam Pembelajaran Di Sd Islam Terpadu Salman Al Farisi Yogyakarta. In eprint UNY. https://eprints.uny.ac.id/9785/

Wibowo, A. E. (2018). Strategi membangun brand image dalam meningkatakan daya saing lembaga pendidikan man 2 ponorogo. https://etheses.iainponorogo.ac.id 